\title{
A forward-thinking scientific article from a Vietnamese billionaire
}

\author{
Ho Manh Toan \\ A.I. for Social Data Lab (AISDL)
}

Hanoi, 06-12-2018

In 2017, Elon Musk published a commentary paper on New Space discussing his SpaceX Mars architecture and what it might mean for humans' space exploration [1]. The decision behinds Musk's publication can be one of these reasons. First, he must have wanted to persuade the public that SpaceX is possible. Second, he needed critical reviews, and perhaps suggestions, from scientists and engineers. Finally, a scientific publication showed his humility and willingness to exchange and discuss ideas.

Scientific publication is an official league for a scientist. However, there are people, who work outside of academia, wishing to contribute their voices too. In 2017, before leaving the White House, former US president Barrack Obama discussed the issue of clean energy on Science [2]. The paper was not his first scientific publication in major journals. In 2006, he co-authored with Hillary Clinton to present their ideas about medical and health reform on the New England Journal of Medicine [3]. Ten years later, he contributed a special communication essay on JAMA [4].

Besides Elon Musk and Barrack Obama, other celebrities also have significant contributions to the scientific dialogue too. Brian May-Queen's famous guitaristis a physicist with publications on Nature [5] and Monthly Notices of the Royal Astronomical Society [6]. The Oscar-winning actress-Natalie Portman-has published in NeuroImage [7] and later obtained a psychology degree from Harvard University.

These publications of famous people suggest that Western societies understand science should not only belong to scientists. However, in a developing country like Vietnam, most people still show skepticism towards science and its cost-effectiveness [8].

Back in 2013, the "Coffee King of Vietnam"—Dang Le Nguyen Vu-published a Web of Science-indexed conference paper about the Vietnamese entrepreneurship 
in troubled times [9]. The paper discusses entrepreneurship in relation to an increasingly important factor-i.e., creative performance and innovation capacitybefore the concept becomes popular in Vietnam. It also is worth noting that in 2013, there was even no pressure for Vietnamese social scientists to publish their work internationally. Thus, the paper represents a very rare vision from a highly successful business icon from the Vietnamese entrepreneurship.

\section{Web of Science}

This content is provided by Web of Science Core Collection, as a free preview.

To access all the content and features, you need a Web of Science Core Collection subscription.

Entrepreneurship and Creativity in Transition Turmoil: The Case of
Vietnam
By: Vu, DLN (Dang Le Nguyen Vu) ${ }^{[1]}$; Napier, NK (Napier, Nancy K.); Hoang, VQ (Vuong Quan Hoang)
View ResearcherID and ORCID
PROCEEDINGS OF THE INTERNATIONAL CONFERENCE ON MANAGEMENT, LEADERSHIP AND
GOVERNANCE
Edited by: Ribiere, V; Worasinchai, L
Pages: $329-339$
Published: 2013
Document Type: Proceedings Paper
Conference

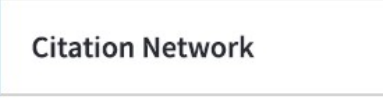

0 Times Cited

44 Cited References

(data from Web of Science Core Collection)

This record is from:

Web of Science Core Collection

Suggest a correction

The paper hypothesizes that a typical "entrepreneurial process carries with it 'creativity-enabling elements'" [9]. To find out the answer, the authors thoroughly reviewed extant literature on the topics, then analyzed the survey data of 137 responses from Vietnamese entrepreneurs and corporate managers. The result suggests what has become a common knowledge nowadays: creativity is important for entrepreneurship. These two critically important elements of the business world have formed the so-called creativity-entrepreneurship nexus.

For some reasons, the paper has not received its first citation yet although entrepreneurship has become a buzzword in Vietnam, and the creativityentrepreneurship nexus has gradually become generally accepted by the public. Nowadays, the public spends more time discussing Dang Le Nguyen Vu's personal life than his meaningful contributions to the development of entrepreneurship in Vietnam. However, his publication will remain a genuine contribution to the academic dialogue on entrepreneurship and creativity, helping to address the 
imperative need of the public for improved understanding of the nature of entrepreneurial processes as well as business education [10].

\section{References:}

[1] Musk, E. (2017). Making humans a multi-planetary species. New Space, 5(2), 4661. DOI: 10.1089/space.2017.29009.emu

[2] Obama, B. (2017). The irreversible momentum of clean energy. Science, 355(6321), 126-129.

[3] Obama, B. (2016). United States health care reform: progress to date and next steps. JAMA, 316(5), 525-532.

[4] Clinton, H. R., \& Obama, B. (2006). Making patient safety the centerpiece of medical liability reform. New England Journal of Medicine, 354(21), 22052208.

[5] Hicks, T. R., May, B. H., \& Reay, N. K. (1972). MgI emission in the night sky spectrum. Nature, 240(5381), 401.

[6] Hicks, T. R., May, B. H., \& Reay, N. K. (1974). An investigation of the motion of zodiacal dust particles-I: Radial Velocity Measurements on Fraunhofer Line Profiles. Monthly Notices of the Royal Astronomical Society, 166(2), 439-448.

[7] Baird, A. A., Kagan, J., Gaudette, T., Walz, K. A., Hershlag, N., \& Boas, D. A. (2002). Frontal lobe activation during object permanence: data from near-infrared spectroscopy. NeuroImage, 16(4), 1120-1126.

[8] Vuong, Q. H. (2018). The (ir)rational consideration of the cost of science in transition economies. Nature Human Behaviour, 2(1), 5, DOI:

10.1038/s41562-017-0281-4.

[9] Vu, D. L. N., Napier, N. K., \& Hoang, V. Q. (2013). Entrepreneurship and creativity in transition turmoil: The case of Vietnam. In V. Ribiere \& L. Worasinchai (Eds.), Proceedings of the International Conference on Management, Leadership and Governance (pp. 329-340). Bangkok University ICMLG 2013. United Kingdom: Academic Publishing.

[10] Hoang, V. Q., \& Dung, T. T. (2009). The cultural dimensions of the Vietnamese private entrepreneurship. The IUP Journal of Entrepreneurship Development, 6(3/4), 54-78. 